\title{
Microbiological Water Evaluation from Biofilm Adhered to Dental Unit Waterlines
}

\author{
Evaluación Microbiológica del Agua de Biofilm \\ Adherido a Líneas de Agua de la Unidad Dental
}

Altamir Oliveira de Figueiredo-Filho'; Jessica Silva Peixoto Bem"; Carlos Roberto Weber Sobrinho² \& Fábio Barbosa de Souza ${ }^{3}$

FIGUEIREDO-FILHO, A. O.; BEM, J. S. P., SOBRINHO, C. R. W. \& SOUZA, F. B. Microbiological water evaluation from biofilm adhered to dental unit waterlines. Int. J. Odontostomat., 13(3):357-362, 2019.

ABSTRACT: The contamination of the dental units' waterlines is a reality, which can develop individual and collective disorders. The aim of this study was to evaluate the prevalence and resistance profile of bacteria on the internal surfaces of waterlines in a dental clinic from a Dentistry school of a Brazilian university. The design was an exploratory, descriptive study with quantitative and qualitative approach. Samples $(n=4)$ were collected for analysis at different points: the portion closest to the water reservoir of the chair, and the portion closest to the triple syringe. After collection the samples were cultured in $\mathrm{BHI}$ medium in an oven for $24-48 \mathrm{~h}$ at $37^{\circ} \mathrm{C}$. For the quantitative analysis $1 \mathrm{ml}$ of each sample was used for serial dilution up to the dilution value seven. The colonies were counted after pour plate and the results expressed in $\mathrm{UFC} / \mathrm{cm}^{2}$. The qualitative analysis was initiated with the cultivation of Agar Blood, EMB-Levine and Cetrimide Agar for $24 \mathrm{~h}$, and the identification of bacteria was performed by microscopic analyses. The resistance profile was verified by classical antibiogram. The internal surfaces of unit waterlines units exhibited a mean of $2.44 \times 109 \mathrm{CFU} / \mathrm{cm}^{2}$. Bacillus subtilis and Pseudomonas aeruginosa were identified. The resistance profile of Pseudomonas aeruginosa indicated sensitivity to all tested antibiotics. A large number of microorganisms was quantified from biofilm accumulated in the dental units' waterlines. However, they were not resistant to classic antibiogram. Better management and application of decontamination protocols for waterlines need to be applied since opportunistic infections may be associated with Pseudomonas aeruginosa.

KEY WORDS: water, biofilms, equipment contamination, infection control.

\section{INTRODUCTION}

Most of dental procedures use large amounts of water for irrigation, instrument cooling, and mouth rinsing. During service, the use of hand pieces allows the formation of a cloud of droplets and aerosols in the environment. It can serve as a source of respiratory and ocular infection for patients and dentists. According to Garg et al. (2012) water may be ingested by the health service user or may contact mucosal and / or teeth continuity solutions. It provides direct access to connective tissue and turns possible absorption and reach of circulatory system. Value water's quality plays an important role in the maintenance of appropriate practices of hygiene and control of cross-infections since waterlines' contamination can be source of disease.
O'Donnell et al. (2006) evaluated the dental chair as a complex medical device designed to provide the dentist with necessary features for a wide variety of dental procedures. In these units, the water supply can arise from a reservoir, replaceable, independent, in the form of a bottle or from the water supply network (O'Donnell et al., 2007). The pipes through which the water passes are called waterlines and are made up of internal surfaces of long lumen plastic (pipes of about $10 \mathrm{~m}$ in length and 0.5 to $1.0 \mathrm{~mm}$ in diameter). These characteristics when associated to the stagnation of water for most of the time, and microscopic internal imperfections constitute a favorable environment for the establishment of microorganisms already present in the water supply (Ajami et al., 2012). The consequent formation of biofilm

\footnotetext{
${ }^{1}$ Federal University of Pernambuco, School of Dentistry. Recife, Pernambuco, Brazil.

2 Department of Biosciences, Federal University of Pernambuco. Recife, Pernambuco, Brazil.

${ }^{3}$ Department of Prosthodontics and Oral Facial Surgery, Federal University of Pernambuco. Recife, Pernambuco, Brazil.
} 
is directly responsible for the contamination of water used in clinical procedures (Walker et al., 2003; Walker \& Marsh, 2004; Walker \& Marsh, 2007; Szymánska \& Sitkowska, 2012; Rodrigues et al., 2017).

Regarding the microorganisms present in water, they are predominantly gram-negative aerobic heterotrophic bacteria which attaches the inner surface of dental equipment tubing creating micro colonies that will lead to multiple biofilm patterns. This biofilm consists primarily of highly hydrated bacterial polysaccharides capable of communicating through pores and channels forming structured, coordinated, and functional communities. With the development of biofilm, planktonic cells and by-products are released into the water directly into patients' mouths during dental procedures (O'Donnell et al., 2007; Wirthlin \& Roth, 2015). Different species of microorganisms in the biofilm do not survive in isolation, but through a system called quorum sensing. This signaling system is based on the ability of not only monitoring the presence of other bacteria around it, but also the production and response to signaling molecules. These auto-inducers are detected by specific receptors that allow the cells to evaluate the population contingent by signal concentration. Upon reaching a critical level, microorganisms act as a single multicellular organism, being able to organize unified responses favorable to population survival (Davies et al., 1998; Sola et al., 2012).

The presence of a high density of microorganisms in the water exit on dental equipment is a potential risk for infections in patients and professionals, not to mention its role on cross-infections. Previous studies have reported the presence of bacteria such as Pseudomonas, Legionella and non-tuberculous (atypical or fast-growing) mycobacteria in the water outlets what is a risk for infection, especially in immunocompromised patients (O'Donnell et al., 2007).

So far, however, there has been little discussion about the sources of contamination of dental work unit pipelines, the present study aimed to quantitatively and qualitatively assess the prevalence and resistance profile of bacteria from the internal surfaces of the dental units waterlines in a Dental School of a public university in the state of Pernambuco, Brazil.

\section{MATERIAL AND METHOD}

The research consisted of an exploratory, laboratory-based field study, which took place at the
Clinic of Oral Medicine and Microbiology and Immunology Laboratory, both at the Health Sciences Center of Federal University of Pernambuco after authorizations for execution were granted through letters of agreement.

A sample, corresponding to $50 \%$ of dental work units on the same clinic, was used to perform the tests $(n=4)$. Only those equipment found in perfect working order (without any of its constituent parts broken or with problems that would jeopardize its use) were randomly selected and evaluated at the time of collection, which occurred at the end of a work shift.

After emptying the aqueous contents of the unit pipes and disinfecting the external surfaces with $70 \%$ alcohol, two fragments of the triple syringe hose were collected from each dental equipment. These 1-cmlong portions were taken at predetermined points: (1) region closest to the triple syringe, called "Exit" and (2) the region closest to the water reservoir, called "Inlet". This step was performed by a single operator, previously trained, and equipped with personal protective equipment (PPE) as well as needle holders, and sterile scalpels.

After cutting, each portion was sectioned longitudinally in order to expose the hose's inner and facilitate contact with the culture media. Subsequently, the samples were placed in a test tube containing $5 \mathrm{~mL}$ of Brain Heart Infusion (BHI), shaken for 1 minute and grown in an oven for $24-48 \mathrm{~h}$ at $37^{\circ} \mathrm{C}$.

For the quantitative analysis, the Pour Plate technique was chosen using serial dilution from $1 \mathrm{~mL}$ of each initial sample. The colonies were counted after incubation for $24-48 \mathrm{~h}$ at $37^{\circ} \mathrm{C}$, using the correction factor for the dilution title. In order to determine the values of colony forming units per square centimeter $\left(\mathrm{CFU} / \mathrm{cm}^{2}\right)$, the internal area of the tube was taken into account. It has been calculated after measuring the lumen diameter of the hose obtained through a previously calibrated digital caliper.

The qualitative analysis was initiated with bacterial growth during $24 \mathrm{~h}$ in three different culture medium: Blood Agar, Eosin Methylene Blue Agar (EMB-Levine) and Cetrimide Agar. The identification of bacteria was performed by means of microscopic analyzes based on cell wall structure and composition (Gram staining). Non-fermenting gram-negative bacteria were identified through the API 20E system. Grampositive bacteria were identified through their hemolysis 
pattern in Blood Agar and through classical phenotypic characteristics, for instance antibiotic sensitivity tests, Catalase and Coagulase tests.

The resistance profile of the microorganisms was verified by means of phenotypic tests such as the classical antibiogram, as recommended by CLSI (2016), using the following drugs: Azitreonam $30 \mathrm{mg}$, Meropenem $10 \mathrm{mg}$, Imipenem $10 \mathrm{mg}$, Gentamicin 10 $\mathrm{mg}$, Amikacin $30 \mathrm{mg}$, Cefepime $30 \mathrm{mg}$, Ciprofloxacin 5 $\mathrm{mg}$, Ceftazidime $30 \mathrm{mg}$, Nonfloxacin $10 \mathrm{mg}$, Levofloxacin $5 \mathrm{mg}$.

The data analysis in this work took the form of a descriptive study, both for the quantity of CFU $/ \mathrm{cm}^{2}$, as well as for the qualitative identification of the isolated bacteria.

\section{RESULTS}

There was bacterial growth in the three culture media (Blood Agar, EMB-Levine and Cetrimide Agar). Only the Input sample from kit 4 (E4) did not show growth after incubation. The results obtained from quantitative analysis are presented in Table I. The mean value was 2.44 x $109 \mathrm{CFU} / \mathrm{cm}^{2}$.

Table I. Relation of the amounts of bacteria found in each sample.

\begin{tabular}{cl}
\hline SAMPLE & AMOUNT in UFC/cm \\
\hline E1 & $1,56 \times 10^{9}$ \\
S1 & $4,05 \times 10^{9}$ \\
E2 & $1,48 \times 10^{9}$ \\
S2 & $5,0 \times 10^{8}$ \\
E3 & Countless (very high values of bacteria found) \\
S3 & Countless (very high values of bacteria found) \\
E4 & There was no growth \\
S4 & $4,63 \times 10^{9} \quad$ \\
\hline
\end{tabular}

For qualitative evaluation, all samples presented growth in Blood Agar, while only Input of equipment 3 (E3) and Output of equipment 3 (S3) had colonies in EMB-Levine and Cetrimide Agar. The microorganisms at E1, S1, E2, S2 were shown as non-sporulated grampositive bacilli. $\mathrm{S} 4$ sample presented as a sporulated gram-positive bacillus. E3 and S3 pointed out the presence of Gram-negative bacilli. The species of the bacteria found are listed in Table II.

The following drugs determined the resistance profile of Pseudomonas aeruginosa: Azitreonam $30 \mathrm{mg}$,
Meropenem $10 \mathrm{mg}$, Imipenem $10 \mathrm{mg}$, Gentamicin 10 mg, Amikacin 30 mg, Cefepime 30 mg, Ciprofloxacin 5 $\mathrm{mg}$, Ceftazidime $30 \mathrm{mg}$, Nonfloxacin $10 \mathrm{mg}$, Levofloxacin $5 \mathrm{mg}$. Interestingly, the colonies in question were sensitive to all of the drugs cited above.

Table II: Relation of the bacteria identified in each sample.

\begin{tabular}{cc}
\hline SAMPLE & BACTERIA \\
\hline E1 & Bacillus subtilis \\
S1 & Bacillus subtilis \\
E2 & Bacillus subtilis \\
S2 & Bacillus subtilis \\
E3 & Pseudomonas aeruginosa \\
S3 & Pseudomonas aeruginosa \\
E4 & - \\
S4 & Bacillus subtilis \\
\hline
\end{tabular}

\section{DISCUSSION}

The first case in literature that demonstrated the direct correlation between a patient's lethal infection and water from dental services units was published in 2012. An 82-year-old female patient with no underlying diseases was admitted to the intensive care unit in an Italian hospital with fever and respiratory problems coming to death two days later. Her death was attributed to pneumonia (Legionella spp.) and the source of infection being the waterlines of her dentist's office was confirmed by three microbiological methods (Ricci et al., 2012).

Regarding biosafety practices, the American Dental Association (ADA) and the US Centers for Disease Control and Prevention (CDC) regulate the quality of water used in dental procedures. According to them, since 2000 , the water used should contain lessthan 200 colony-forming units per $\mathrm{mL}(\mathrm{CFU} / \mathrm{mL})$ of aerobic, mesophilic and heterotrophic bacteria in non-surgical procedures (Mills et al., 2018).

Although the amount of bacteria present in the water is an indicator for the degree of contamination, analysis of the biofilm formed inside the pipes gains great importance. Inside the waterlines, microorganisms colonize and replicate on the internal surfaces, producing a heterogeneous adherent microbial accumulation (biofilm). Once it is formed, the biofilm protects the organisms and works as a reservoir that alters the number of free-floating microorganisms in the water leaving the hoses (Whitehouse et al., 1991; Barbeau et al., 1998). The microorganisms on the 
surfaces are continuously released from the biofilm in the water passing through the lumen of the tube, so that this biofilm becomes the main reservoir for continued contamination of the system (O'Donnell et al., 2007; Walker \& Marsh, 2004).

In this perspective, considering the way bacteria is released in the environment, this study proposed a different methodology for collecting when compared to researches related to waterlines contamination, since the bacteriological analysis was not performed from the collection of water from the equipment, but from the release of bacteria previously adhered to the pipe (Tuttlebee et al., 2002; Ávila-De-Navia et al., 2014; Micha kiewicz et al., 2015). Thus, the results showed a quantitative related to the internal area of the tube, where the biofilm is formed, not having a comparison with the volume of water collected. In this new parameter, the results showed a quantitative value greater than $108 \mathrm{CFU} / \mathrm{cm}^{2}$ (Table I), a disturbing number that suggests the presence of a large bacterial activity in the equipment system.

Having said that, specimen E4 was the only one showing bacterial non-growth. A likely explanation for this might be the absence of water in the reservoir at the time of collection. It seems possible that the drying of the reservoir after the use would lead to a decrease in the formation of biofilms converging with the recommendations of the Brazilian National Agency of Sanitary Surveillance (ANVISA) for the control of infections in Dentistry. In its manual, the agency recommends in addition to dry maintenance at night and at weekends, the use of water filters in the lines, use of water tank independent of the supply network, chemical disinfection of waterlines and daily drainage (Brasil, 2006).

As far as the qualitative analysis is concerned, only two species of bacteria were found. These data must be interpreted with caution because only tests for aerobic bacteria were conducted. On the other hand, Barbeau et al. hold the view that the water systems of dental units resemble an aquatic ecosystem in which various opportunistic pathogens colonize the inner surface of the pipes. These pathogens consists of microorganisms, including bacteria, fungi and protozoa, which colonize and replicate on the inner surface of water pipes, often forming a protective layer of viscous substance (limo/mucus) that allows them to survive in adverse environments and invade new locations (Brasil, 2006; Sacchetti et al., 2007). In light of that, a reasonable approach to tackle this issue could be to carry out more tests for microorganisms such as fungi and protozoa or anaerobic bacteria, which are found in other studies like those by de Oliveira et al. (2008).

The most frequently bacteria found in this study was $B$. subtilis. Bacteria of this genus were not only frequent in studies conducted in the 1990s (Garg et al.) but also in recent studies as reported by Ji et al. (2016) and Szymanska \& Sitkowska (2012). However, once they refer only to the genus, it is difficult to compare the amount of this species found by them to the one found in the presented study. In addition, this type of microorganism was identified in almost all samples, unlike what was observed in the study by Szyman'ska \& Sitkowska (2013) in which the amount of bacteria from this genus was not significant once the goal was to confirm the contamination of dental units only.

B. subtilis is a gram-positive spore-forming bacterium that typically inhabits water and soil being common in the gastro-intestinal tract of animals. It is important in clinical practice due to its use as biological indicator during sterilization processes (O'Donnell et al., 2006). The other species identified, P. aeruginosa, is the most important human pathogen in the genus Pseudomonas. It is characterized as non-fermenting and ubiquitous Gram-negative rods, since they can be found in soil, water, vegetables, animals, and have a direct relationship with Health Care-Associated Infections (HCAI). HCAl consist of localized or systemic conditions resulting from an adverse reaction to the presence of an acquired infectious agent after admission to health services (CDC, 2014). They must be manifested after 48 hours of admission or prior to that period when related to invasive procedures performed at the health services (Ministério da Saúde, 1998).

Diseases in which microorganisms are visible in the form of biofilms may include: dental caries, periodontitis, pneumonia, septicemia, malfunction of urinary catheters and contact lenses, severe tissue infections (osteomyelitis and endocarditis) aside from rejections of prosthetic material. In patients with cystic fibrosis, about $80 \%$ to $90 \%$ of biofilms are composed solely of Pseudomonas aeruginosa (de Oliveira et al.; Trentin et al., 2013). This bacterium is commonly isolated in analysis of dental units waterlines. Sacchetti et al. in a study comparing the tubes made of Polyethylene and Polytetrafluoroethylene, isolated P. aeruginosa in polyethylene tubes only. de Oliveira et al. isolated 71 samples containing this bacteria from a total of 160 water samples. 
The bacteria identified on the inlet pipeline were the same as those found on the waterline's exit. Moreover, it was observed that the number of colonies found in both collection sites was similar. A resembling result was found by Fernandes et al. (2018), who when performing a quantitative analysis of heterotrophic bacteria in the water of dental equipment, obtained statistically equivalent values for the reservoir and triple syringe.

In spite of being intrinsically resistant to several antimicrobials including chloramphenicol, tetracyclines, some quinolones and beta-lactams, the Pseudomonas aeruginosa colonies submitted to resistance profile verification in this study were sensitive to all tested antibiotics indicating that infections caused by these strains are probably easily combated.

In this investigation all the procedures were standardized and performed following biosafety standards in order to minimize the possible bias inherent to any laboratory research. Also, the use of an innovative methodology requires that more tests should be performed in other clinical settings in order to allow a comparative analysis of the findings.

Most of the bacteria found in the hoses of dental units presented a small risk to immunologically healthy people. Nevertheless, these microorganisms become important infectious agents; especially in predisposed patients presenting damaged physical barriers and immunosuppression. Thus, monitoring of water quality and the detection of pathogenic microorganisms are essential for providing a situational diagnosis, as well as for encouraging biosecurity practices such as avoiding water stagnation and applying water disinfection protocols. Even with a small sample size, the findings of this study suggest the need for better management and application of decontamination protocols for waterlines, since opportunistic infections may be associated with Pseudomonas aeruginosa.

FIGUEIREDO-FILHO, A. O.; BEM, J. S. P., SOBRINHO, C. R. W. \& SOUZA, F. B. Evaluación microbiológica del agua de biofilm adherido a líneas de agua de la unidad dental. Int. J. Odontostomat., 13(3):357-362, 2019,

RESUMEN: La contaminación de líneas de agua en las unidades dentarias es una realidad, generando enfermedades individuales y colectivas. El objetivo de este estudio fue evaluar la prevalencia y resistencia de las bacterias en las zonas internas de las líneas de agua de la Facultad de Odontología de una universidad brasileña. El diseño del estudio fue exploratorio, descriptivo con enfoques cuantitativos y cualitativos. Las muestras para análisis $(n=4)$ fueron selecionadas de distintos lugares: el punto más cercano al sistema de agua del sillón odontológico y el punto más cercano a la jeringa tríplice. Las muestras obtenidas fueron cultivadas en un médio BHI por 24-48 h, en un horno a 37 ${ }^{\circ} \mathrm{C}$. Para el análisis cuantitativo, se utilizó $1 \mathrm{ml}$ de cada muestra para dilución hasta el valor siete. Las colonias fueran contadas y los resultados fueron expresados en UFC/ $/ \mathrm{cm}^{2}$. El análisis cualitativo fue iniciado con el cultivo de Agar Sangre, EBM-Levine y Agar Cetrimide por $24 \mathrm{~h}$ y la identificación de la bacteria fue realizada por análisis microscópicos. El perfil de resistencia fue verificado por el antibiograma clásico. Las zonas internas de las unidades de líneas de agua mostraron un promédio de $2,44 \times 109 \mathrm{UFC} / \mathrm{cm}^{2}$. Bacillus subtilis y Pseudomonas aeruginosa fueron encontrados. El perfil de resistencia de $P$ seudomonas aeruginosa indicó sensibilidad a todos los antibióticos testados. Un gran número de microorganismos fue cuantificado desde la biopelícula acumulada en las líneas de agua de unidades dentales. Sin embargo, no resistieron al antibiograma clásico. Se requiere una mejor gestión y aplicación de protocolos de decontaminación en las líneas de agua debido a que las infecciones oportunistas puedan estar asociadas a Pseudomonas aeruginosa.

PALABRAS CLAVE: agua, biopelículas, contaminación de equipos, control de infecciones.

\section{REFERENCES}

Ajami, B.; Ghazvini, K.; Movahhed, T.; Ariaee, N.; Shakeri, M. \& Makarem, S. Contamination of a dental unit water line system by legionella pneumophila in the mashhad school of dentistry in 2009. Iran. Red Crescent Med. J., 14(6):376-8, 2012.

Ávila-De-Navia, S. L.; Estupiñán-Torres, S. M. \& Estupiñán-Torres, D. M. Indicadores de calidad bacteriológica del agua en unidades odontológicas. Rev. Fac. Med., 62(1):111-7, 2014.

Barbeau, J.; Gauthier, C. \& Payment, P. Biofilms, infectious agents, and dental unit waterlines: a review. Can. J. Microbiol., 44(11):1019-28, 1998.

Davies, D. G.; Parsek, M. R.; Pearson, J. P.; Iglewski, B. H.; Costerton, J. W. \& Greenberg, E. P. The involvement of cell-tocell signals in the development of a bacterial biofilm. Science, 280(5361):295-8,1998.

de Oliveira, A. C.; Maluta, R. P.; Stella, A. E.; Rigobelo, E. C.; Marín, J. M. \& de Ávila, F. A. Isolation of Pseudomonas aeruginosa strains from dental office environments and units in Barretos, state of São Paulo, Brazil, and analysis of their susceptibility to antimicrobial drugs. Braz. J. Microbiol., 39(3):579-84, 2008.

Fernandes, M. C. R.; Lima, P. B.; Calazans, M. T. \& de Souza, F. B. The quality of water in dental offices from the public healthcare system of a Brazilian town: a study of the microbial, physical and chemical parameters. J. Dent. Health. Oral Disord. Ther., 9(5):393-7, 2018.

Garg, S. K.; Mittal, S. \& Kaur, P. Dental unit waterline management: historical perspectives and current trends. J. Investig. Clin. Dent., 3(4):247-52, 2012. 
Ji, X. Y.; Fei, C. N.; Zhang, Y.; Zhang, W.; Liu, J. \& Dong, J. Evaluation of bacterial contamination of dental unit waterlines and use of a newly designed measurement device to assess retraction of a dental chair unit. Int. Dent. J., 66(4):208-14, 2016.

Micha kiewicz, M.; Ginter-Kramarczyk, D. \& Kruszelnicka, I. K. Czy woda w unitach dentystycznych jest bezpieczna? Med. Pr., 66(6):763-70, 2015.

Mills, S. E.; Porteous, N. \& Zawada, J. Dental Unit Water Quality: Organization for safety, asepsis and prevention white paper and recommendations-2018. J. Dent. Infect. Control Safety, 1(1):127, 2018.

O'Donnell, M. J.; Shore, A. C. \& Coleman, D. C. A novel automated waterline cleaning system that facilitates effective and consistent control of microbial biofilm contamination of dental chair unit waterlines: a one-year study. J. Dent., 34(9):648-61, 2006.

O'Donnell, M. J.; Shore, A. C.; Russell, R. J. \& Coleman, D. C. Optimisation of the long-term efficacy of dental chair waterline disinfection by the identification and rectification of factors associated with waterline disinfection failure. J. Dent.,35(5):438$51,2007$.

Ricci, M. L.; Fontana, S.; Pinci, F.; Fiumana, E.; Pedna, M. F.; Farolfi, P.; Sabatinni, M. A. \& Scaturro, M. Pneumonia associated with a dental unit waterline. Lancet, 379(9816):684, 2012.

Rodrigues, S.; Suvarna, S.; Suvarna, J.; Saralaya, V.; Saldanha, S. \& Shenoy, V. K. Microbial assessment of dental unit waterlines in an institutional setup in Karnataka, South India. Indian J. Dent. Res., 28(5):555-9, 2017.

Sacchetti, R.; De Luca, G. \& Zanetti, F. Influence of material and tube size on DUWLs contamination in a pilot plant. New Microbiol., 30:29-34, 2007.

Sola, M.; Oliveira, A.; Feistel, J.; Minafra, C. \& Rezende, C. Mecanismos De Quorum Sensing e sua Relevância na Microbiologia de Alimentos. $8^{\text {th }}$ ed. Goiânia, Enciclopédia Biosfera, Centro Científico Conhecer, 2012.

Szymanska, J. \& Sitkowska, J. Bacterial contamination of dental unit waterlines. Environ. Monit. Assess., 185(5):3603-11, 2012.

Szymanska, J. \& Sitkowska, J. Opportunistic bacteria in dental unit waterlines: assessment and characteristics. Future Microbiol., 8(5):681-9, 2013.

Trentin, D. S.; Giordani, R. B. \& Macedo, A. J. Biofilmes bacterianos patogênios: aspectos gerais, importância clínica e estratégias de combate. Rev. Liberato, 14(22):113-238, 2013.

Tuttlebee, C. M.; O'Donnell, M. J.; Keane, C. T.; Russell, R. J.; Sullivan, D. J. \& Falkiner, F. Effective control of dental chair unit waterline biofilm and marked reduction of bacterial contamination of output water using two peroxide-based disinfectants. J. Hosp. Infect., 52(3):192-205, 2002.

Walker, J. T. \& Marsh, P. D. A review of biofilms and their role in microbial contamination of dental unit water systems (DUWS). Int. Biodeterior. Biodegrad., 54(2):87-98, 2004.

Walker, J. T. \& Marsh, P. D. Microbial biofilm formation in DUWS and their control using disinfectants. J. Dent., 35(9):721-30, 2007.

Walker, J. T.; Brandshaw, D. J.; Fulford, M. R. \& Marsh, P. D. Microbiological evaluation of a range of disinfectant products to control mixed-species biofilm contamination in a laboratory model of a dental unit water system. Appl. Environ. Microbiol., 69(6):3327-32, 2003.

Whitehouse, R. L.; Peters, E.; Lizotte, J. \& Lilge, C. Influence of biofilms on microbial contamination in dental unit water. J. Dent., 19(5):290-5, 1991.

Wirthlin, M. R. \& Roth, M. Dental unit waterline contamination: a review of research and findings from a clinic setting. Compend. Contin. Educ. Dent., 36(3):216-9, 2015.
Corresponding author:

Fábio Barbosa de Souza

Federal University of Pernambuco

Department of Prosthodontics and Oral Facial Surgery

Av. Prof. Moraes Rego s/n

Cidade Universitária

Recife-PE

CEP: 50670-901

BRAZIL

E-mail: fabiobdsouza@gmail.com

Received: 14-12-2018

Accepted: 29-03-2019 